\title{
A New Approach to Permian System in the Section of Gahkum Mountain (Zagros-Iran)
}

\author{
Maryam Abedini1 ${ }^{*}$, Ali Aghanabati², Ali Meisami3 ${ }^{3}$, Davoud Jahani4 \\ ${ }^{1}$ Islamic Azad University, North Tehran Branch, Tehran, Iran \\ ${ }^{2}$ Department of Geology, Faculty of Science, Islamic Azad University, North Tehran Branch, Tehran, Iran \\ ${ }^{3}$ Department of Geology, Islamic Azad University, Boomehen Branch, Boomehen, Iran \\ ${ }^{4}$ Department of Geology, Islamic Azad University, North Tehran Branch, Tehran, Iran \\ Email: *ma2006geo@yahoo.com
}

How to cite this paper: Abedini, M., Aghanabati, A., Meisami, A. and Jahani, D. (2017) A New Approach to Permian System in the Section of Gahkum Mountain (Zagros-Iran). Open Journal of Geology, 7, 965-977.

https://doi.org/10.4236/ojg.2017.77065

Received: January 27, 2017

Accepted: July 18, 2017

Published: July 21, 2017

Copyright $\odot 2017$ by authors and Scientific Research Publishing Inc. This work is licensed under the Creative Commons Attribution International License (CC BY 4.0).

http://creativecommons.org/licenses/by/4.0/

\begin{abstract}
The deposits of Permian system in Kuh-e-Gahkum consist of $480 \mathrm{~m}$ clastic subdiffusion of Faraghan Formation and carbonates of Dalan Formation. In this section, the sediments of Faraghan Formation, which is gradationally overlain by Dalan formation, unconformably overlies Zakin Formation (Lower Carboniferous). In the upper part, Kangan Formation rests on the Permian deposits with an erosional and unconformable contact. Studying the microscopic thin sections led to the identification of 37 genera and 37 species of Foraminifera as well as 14 genera and 15 species of algae. According to the identified foraminifera in Faraghan and Dalan Formations, the age of the rock units in Permian system is assigned to Julfian-Asselian.
\end{abstract}

\section{Keywords}

Permian, Gahkum, Zakin Formation, Dalan Formation, Foraminifera

\section{Introduction}

Similar to other parts of Iran and its neighbors, Permian progradational sequences (Faraghan Formation and its equivalences) are deposited in Zagros structural-sedimentary zone after a long period of erosion resulting from various phases of Hercynian tectonic, and finally reach to the upper Permian marine deposits (Dalan formation and its equivalences).

Given the above-mentioned erosion period, progradational subdiffusions have clastic origin and are mostly composed of sandstone in fluvial environments, particularly in intermediate deltaic environments. Therefore, a dozens of highly different views have been presented as they represent poor paleontological data.

Regarding the lithological studies and gathered microfossils, the age of the 
progradation of the Permian sea, like other parts of Iran, is estimated to be Asselian-Sakmarin, representing most Lower Permian.

In the past, sandstones of Faraghan Formation represented Permo-carboniferous rocks while they sometimes reminded geologists of Devonian strata. However, current painstaking studies carried out on foraminifera reveal that this stratigraphic unit belongs to the Early Permian progradational strata.

In most areas, the lower boundary of the sandstones of Faraghan Formation shows unconformity while its upper boundary with carbonates of Dalan Formation (Permian) is of gradational type.

Dalan Formation with Middle-to-Upper Permian age is composed of carbonate facies, often interbedded with evaporite and is recognized as one of the most important gas carbonate formations in folded Zagros and vast area of the Persian Gulf [1].

Gahkum section is mostly characterized by Upper Permian carbonate deposits, known as Dalan formation. This stratigraphic unit is deposited in various parts of Zagros sedimentary basin.

Form the past to present, most of the geology literature has been conducted in western or southwestern Zagros zone, where the largest global oilfields are situated. This study is the first to study foraminifera, together with algae contained in the Permian rock units in southeastern Zagros zone. The importance of this study lies in the fact that this study, carried out at the outmost part of southeastern Zagros, cannot only examine biological and lithological characteristics, but also draws explicit conclusion about Paleogeography of the eastern Permian sea in Zagros zone.

To conduct a meticulous study on Permian system in Zagros zone, one of its outcrops in Kuh-e-Gahkum in northern Bandarabbas City was stratigraphically and paleontologically examined.

\section{Geological History}

Szabo [2] studied the stratigraphy of the Permian and Triassic in Zagros basin and recognized two important unconformities in lower Permian and upper Triassic and one sedimentary gap between Triassic and Permian deposits. Szabo [2] reported the permotriassic stratigraphy in Kuh-e-Gahkum. He reports no outcrop at the boundary of Dalan and Faraghan Formations, and no gypsum layer was observed in Dalan Formation. In a report entitled The stratigraphy of the sedimentary units of Central Zagros and Lorestan Mountains, he assigned Lower Permian deposits to Ordovician age or even older, whereas he assigned them to Silurian age in Faraghan and Gahkum areas (northern Bandarabbas).

According to Szabo and Kheradpir's [3] classification, Faraghan Formation is a basal member of Dahram group. As such, it lies on various old units and shows an angular unconformity in its boundary with lower units. Accordingly, Faraghan Formation is interpreted as deposits of a progradational sea, and its lower boundary is believed to be the result of mid-carboniferous tectonic activity. Due to the lack of marine fauna, therefore, the age of the deposits of Faraghan For- 
mation, defined by Szabo and Kheradpir, has always been the source of controversy among geologist.

In the past, sandstones of Faraghan Formation showed the characteristics of permo-carboniferous rocks and sometimes reminded us of Devonian strata [4] [5].

Ghavidelsivaki [6], in an unpublished $\mathrm{Ph}$. D dissertation, conducted a systematic study on the palynomorphs extracted from sandstones and shales of Faraghan Formation and detected five biozones, among which biozones 4-1 shows Lower Devonian to Upper Devonian age while the age of biozone 5 is Lower Permian. Hence, he divided this formation into two parts, namely Zakin and Calisheh, which are assigned to Devonian and Lower Permian, respectively. The most documented and reliable paleontological data have palynologic origin, which assign Faraghan formation to Sakmarian and Kangurian ages [7].

\section{Methodology}

The studied section is formed by geographical coordinates of $12^{\circ} 05^{\prime} 28^{\prime} \mathrm{N}$ and $55^{\circ} 56^{\prime} 50^{\prime} \mathrm{E}$, and is located in Kuh-e-Gahkum in Abzagh valley, about 125 kilometers from northern Bandarabbas city, in Bandarabbas-to-Sirjan road and close to Sarchahan village (about $13 \mathrm{~km}$ from Sarchahan village) (Figure 1, Figure 2).

Having selected the studied section, the contacts of the formations were detected and then a number of microscopic thin sections were systematically collected from rock units of Zakin, Faraghan and Dalan. It is noteworthy that field operation was performed on several occasions, during which sampling was undertaken in shorter distance when needed. Then microscopic thin sections collected from the sample sites were studied by polarizing microscope with ordinary light. After that, some thin sections were derived from the collected samples, and finally some images were taken from the striking fossil specimens.

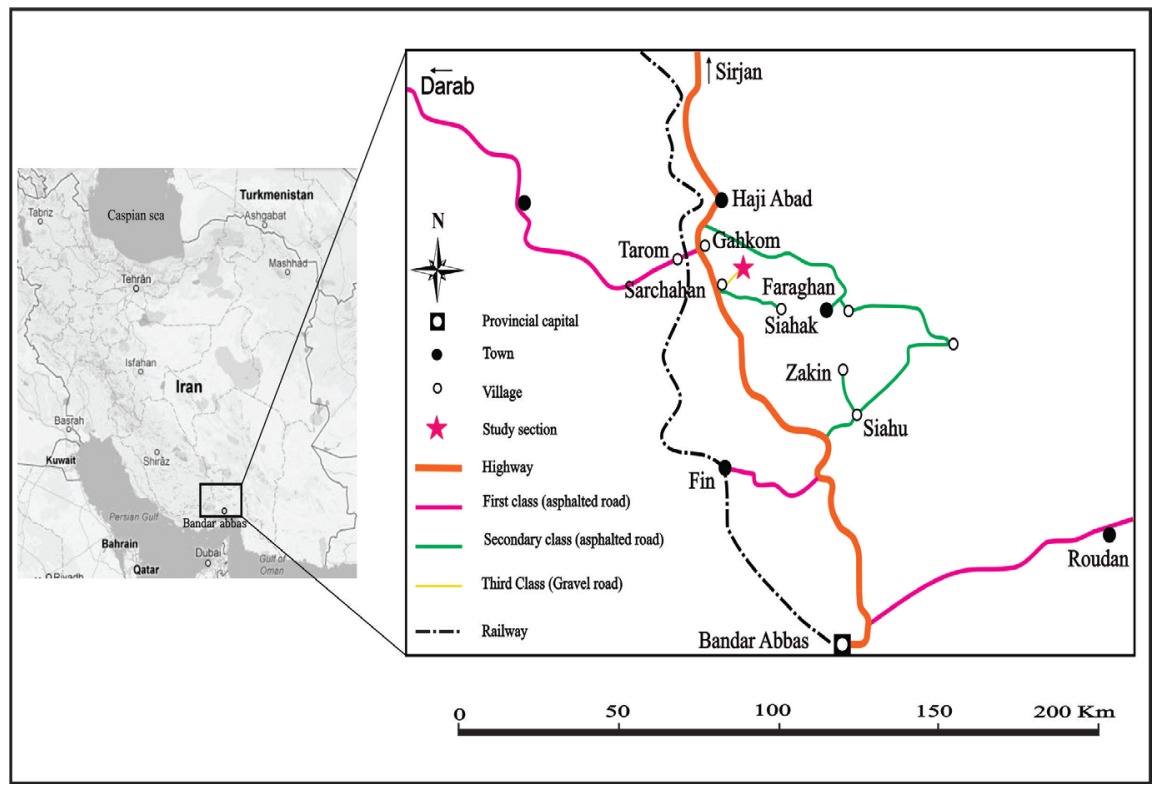

Figure 1. Geographical setting and access ways to the studied section [8]. 


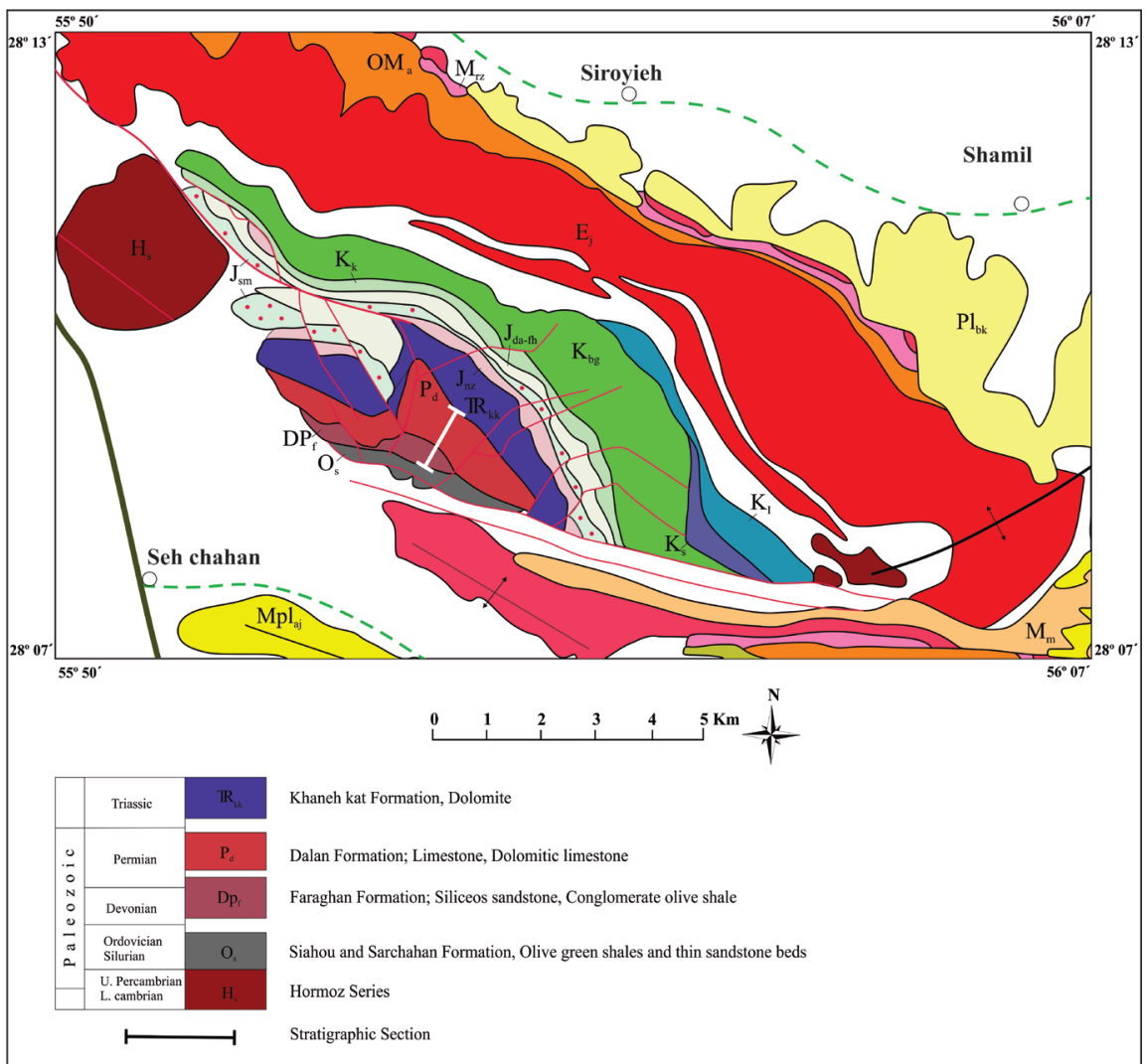

Figure 2. Geological map of Kuh-e-Gakum section [12] [13].

Faraghan and Dalan. Reliable sources like Loeblich and Tappan [9], Khosrowtehrani [10], Kalantari [11] was also employed to recognize foraminifera.

\section{Discussion}

\subsection{Lithostratigraphy of Permian System}

Gahkum section encompasses the sedimentary sequences of Sarchahan, Zakin, Faraghan and Dalan Formations (Figure 3). The lower subdiffusions of Permian sediments are composed of gray-to-dark gray silty shales, which are assigned to Sarchahan Formation with Silurian age and in most parts, lead to conglomerate of Zakin Formation, which is separated from this formation via unconformity. According to the studies, Zakin Formation in Gahkum section of Abzagh area is $220 \mathrm{~m}$ thick. This formation is restricted by two erosional unconformities. It hosts conglomerate, a sequence of gray-to-brown sandstones and thin-to-medium bedded lime, ending up in gray, medium layered lime.

Faraghan Formation unconformably rests on Zakin Formation. According to the studies, Faraghan Formation in Gahkum section of Abzagh area is $60 \mathrm{~m}$ in thickness. This formation is composed of $6 \mathrm{~m}$ basal conglomerates including quartz conglomerate with semi-rounded cobbles which are encapsulated by sandstone and silica cement, and $54 \mathrm{~m}$ sandstone interbedded with shale and lime including deltaic-fluvial, medium-to-fine grained quartz sandstone, which consists of sequences of shale and lime layers. It has unconformable contact with 


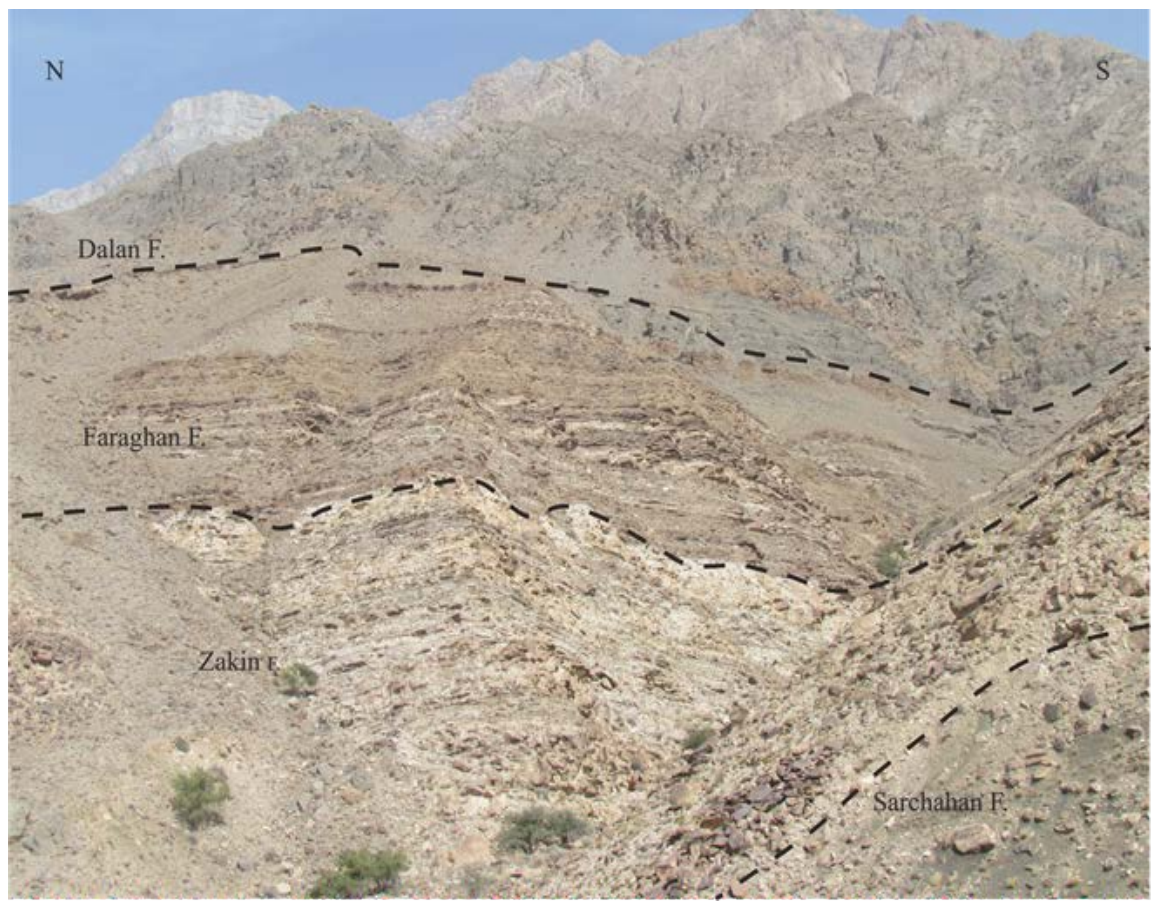

Figure 3. An image of the outcrops of Sarchahan, Zakin, Faraghan and Dalan Formations in Gahkum section; northwestern view.

Faraghan clastic formation at the bottom and Kangan carbonate formation at the top.

The second lithostratigraphyic unit of Permian system is placed in Kuh-eGahkum of Dalan Formation. It forms a gradational and conformable contact with Lower Faraghan Formation and erosional and unconformable one with Upper Kangan Formation.

Dalan formation accounts for the marine carbonate facies of the Upper Permian strata in Zagros area and is highly expanded in high Zagros, Fars area and Persian Gulf. As a subterraneous section, it is $748 \mathrm{~m}$ thick and located within Kuhsiah \# 1 oil well. Its best surface outcrop is $638 \mathrm{~m}$ thick, exposed in Kuh-eSurmeh (110 km from southern Shiraz city)) [7].

This formation hosts a set of evaporite-carbonate strata. Its lithological changes depend on the facies changes in various settings. The sample section shows both evaporite and carbonate lithology [14].

In the studied section, Dalan formation has overlain Faraghan formation as its lithology has gradationally changed (Figure 4).

According to the field observations, Dalan formation in Gahkum section of Abzagh area is 420 in thickness. The sedimentary strata (units) of this formation are composed from the bottom up of:

1- $180 \mathrm{~m}$ grey-to-beige, medium-to-thick bedded, fossil-rich limestone.

2- $70 \mathrm{~m}$ beige-to-brown, rock-producing, dolomite and mass limestone.

3- $170 \mathrm{~m}$ dark grey-to-grey, medium, fossil-rich limestone

Various microfacies including grainstone, mudstone, packstone and wackstone were identified in this unit based on Dunham's [15] classification. Broken 


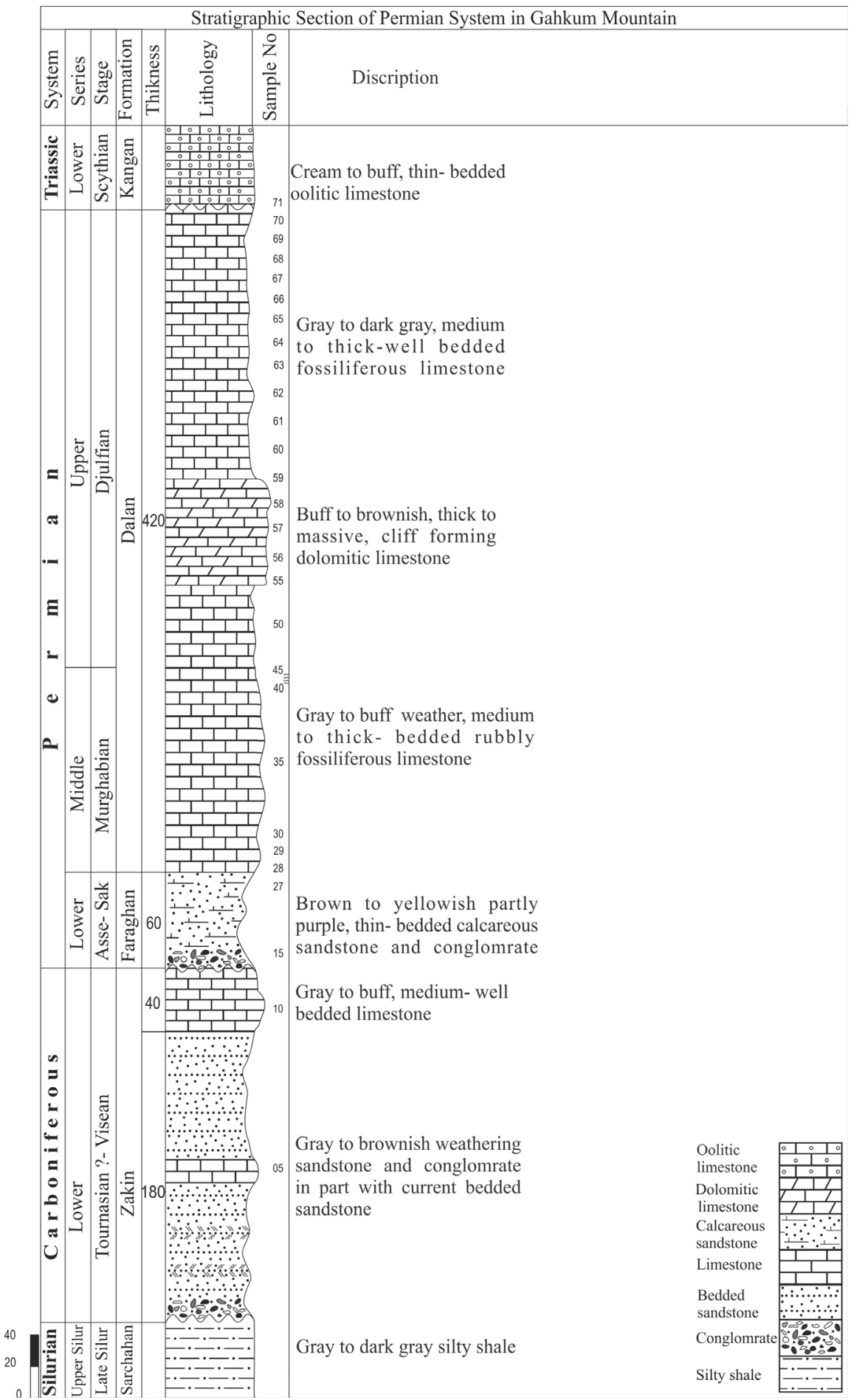

Figure 4. Stratigraphic column of Kuh-e-Gahkum section.

pieces of shell, Echinoid, Bryozoa fragments together with foraminifera play an important role in building stone microfacies of this formation.

The retreat of the sea in the late Permian has contributed to the erosional activities in the shallow parts of Zagros sedimentary basin and thus absence of stratigraphy. Therefore, the upper boundary of Dalan Formation is characterized by lack of stratigraphy and a slight conformity [14]. In this section, the transition 
from Dalan Formation to the thin-bedded limestones of Kangan Formation is recorded as an erosional unconformity with no stratigraphy.

\subsection{Biostratigraphy of Permian System}

In the studied section, the biological faunas consisting of foraminifera and algae were identified (Plates 1-4). Regarding the development of foraminifera and algae in the Permian system of Kuh-e-Gahkum (Figure 5), this system can be divided into three time periods based on biostratigraphy:

1- Asselian-Sakmarian time period (Early Permian), which is identified from the presence of foraminifera: Geinitzina reperta, Geinitzina postcarbonica, Langella ocarina S.DE civrieux \& Dessauvagie, Globivalvulina sp.

And algae: Gymnocodium bellerophontis (Rothpletz), Tubiphytes obscurus, Permocalculus tenellus (PiaPermocalculus forcepinus (Johnson)

This time period covers the whole body of Faraghan formation.

2- Morghabin time period (Middle Permian), which is characterized by the presence of foraminifera and contains the limestones and dolomitized and crystalized limestones of Dalan formation.: Langella ocarina, Globivalvulina vonderschmitti, Geinitzina reperta, Geinitzina postcarbonica, Tuberitina

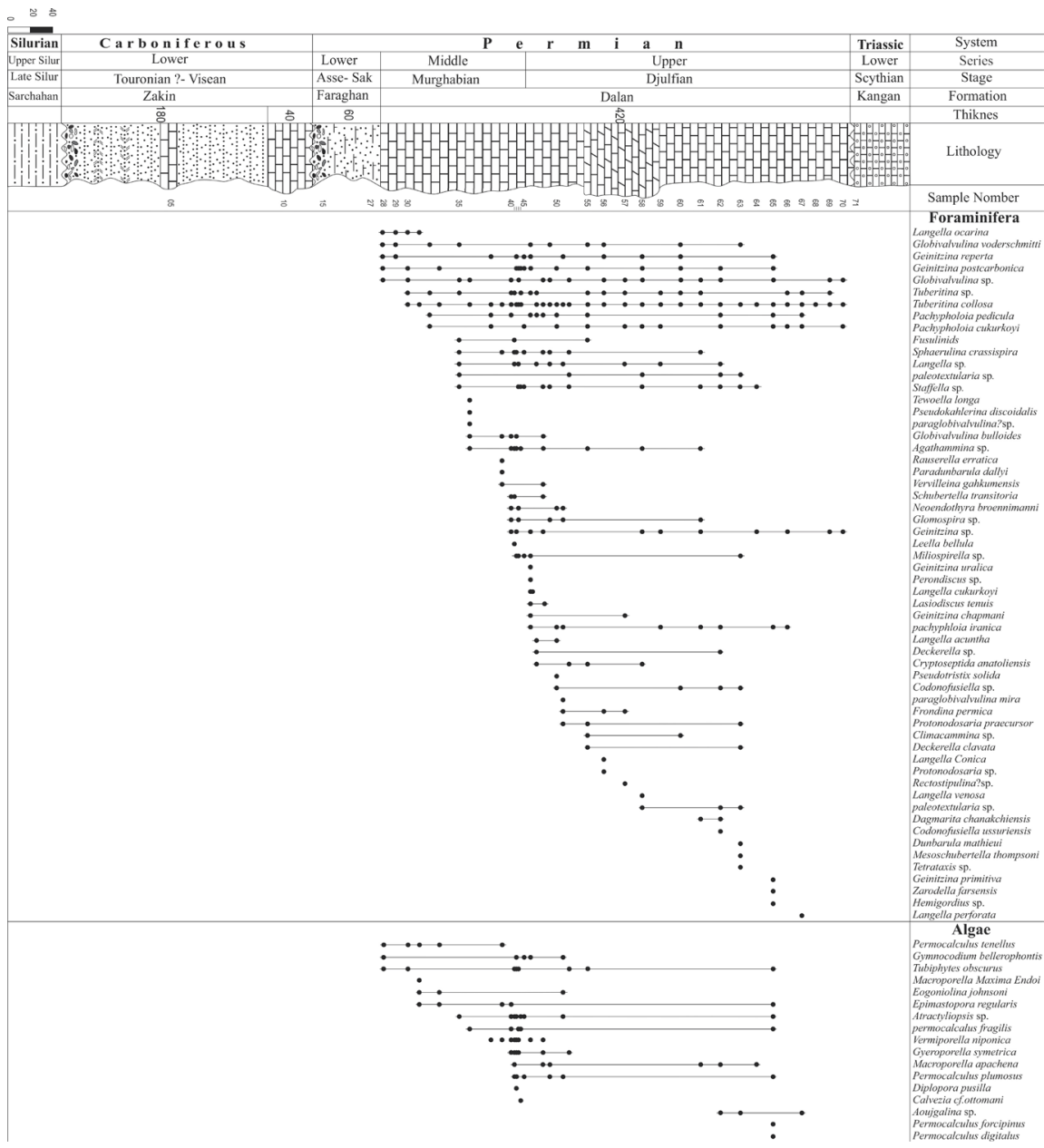

Figure 5. Species range of foraminifera and algae at Gahkum section. 

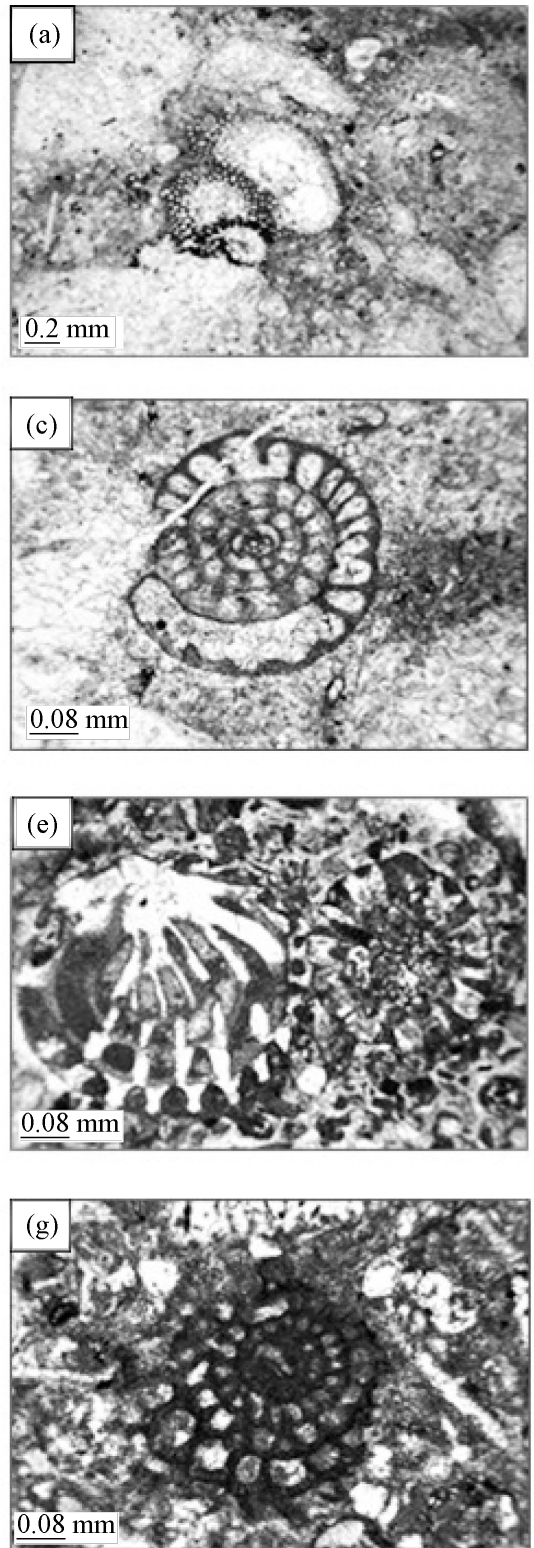
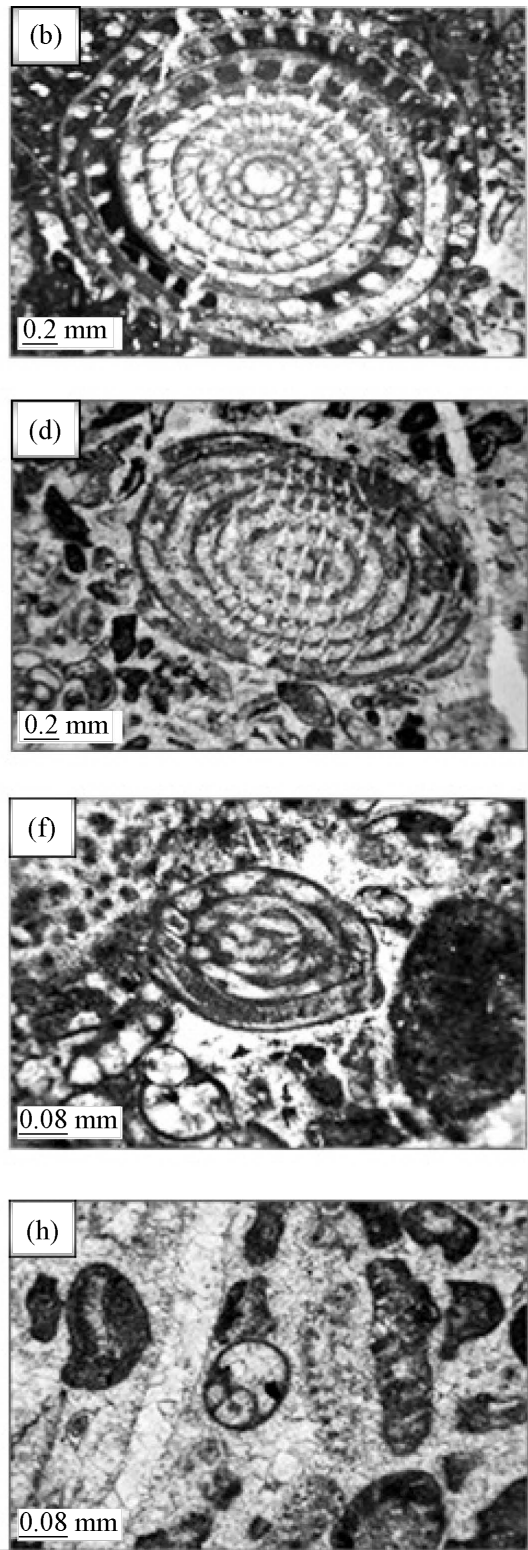

Plate 1. (a) Vervilleina gahkumensis n.sp.,x e long.sec Gahkum sec., Dalan Fm., sample no.,39-3, Early Murghabian; (b) Diplopora pusilla k.\&H.,x e long.sec Gahkum sec., Dalan Fm., sample no.,42-1, Late Murghabian; (c) Paradunbarula dallyi Skinner.,x e long.sec Gahkum sec., Dalan Fm., sample no.,39-1, Early Murghabian; (d) Sphaerulina crassispira J.S.Lee,x e long.sec Gahkum sec., Dalan Fm., sample no.,49-1, Djulfian; (e) (f) staffella sp., (e): staffella sp., Macroporella apachena Johnson,sul.,x e long.sec Gahkum sec., Dalan Fm., sample no.,66-4 , Djulfian; (f) x e long.sec Gahkum sec., Dalan Fm., sample no.,42-9, Late Murghabian; (g) Fusulina sp.,x e long.sec Gahkum sec., Dalan Fm., sample no.,51-1,51-3 ,Djulfian; (h) paraglobivalvulina mira Reitliger., x e long.sec Gahkum sec., Dalan Fm., sample no.,48-2, Djulfian.

collosa, Pachyphloia pedicula, Pachyphloia cukurkoyi, Sphaerulina crassispira, Tewoella Longa, Pseudokahlerina discoidalis, Globivalvulina bulloides, Rauserella erratica, Paradunbarula dallye, Vervilleina gahkumensis, Schubertella transitoria, Neoendothyra bronennimanni, Leella bellula, Globivalvulina sp., Tuberitina sp., Langella sp., Palaeotextularia sp., Staffella sp., Paraglobi 

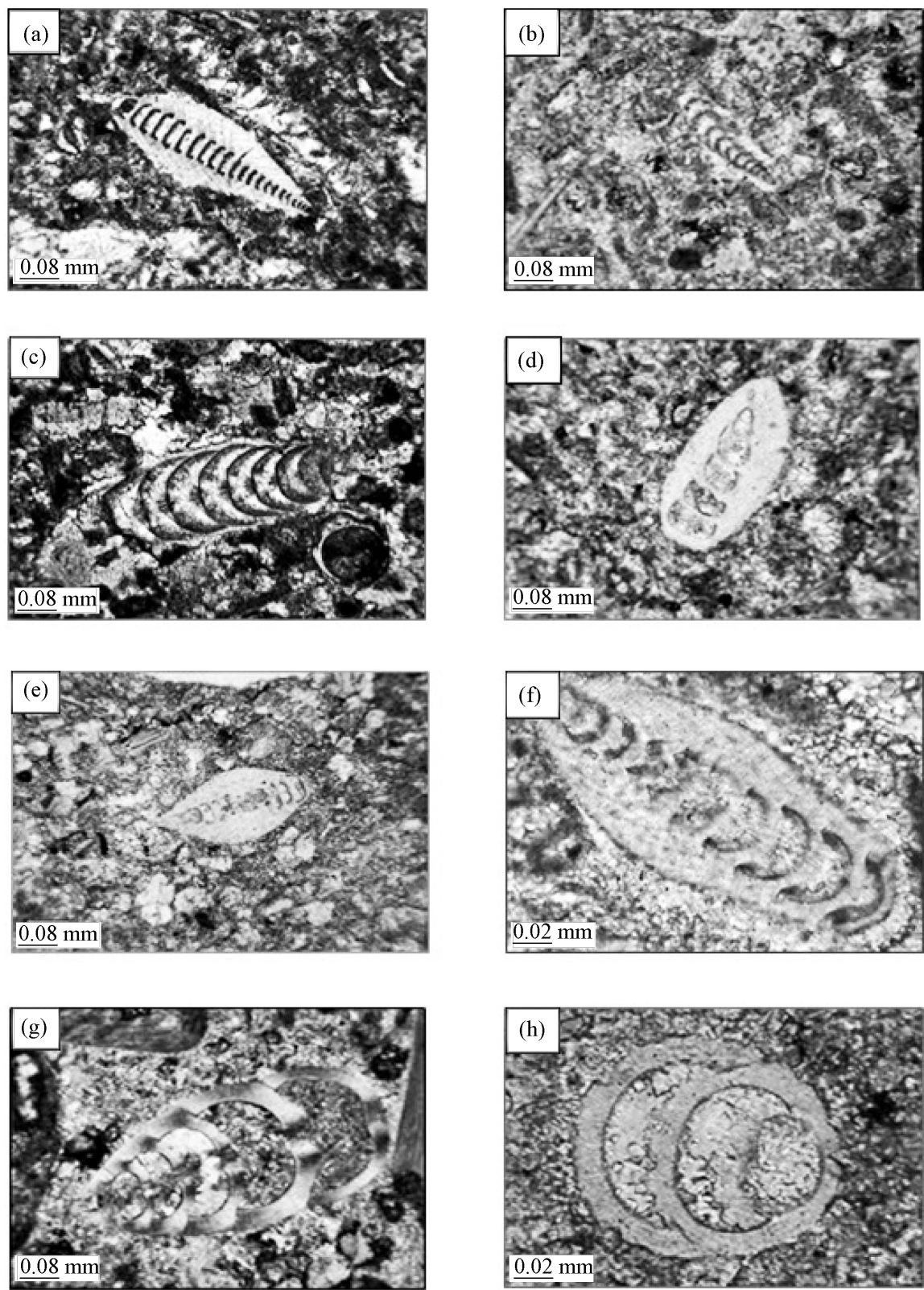

Plate 2. (a) Geinitzina reperta Bykova., x e long.sec Gahkum sec., Dalan Fm., sample no.,53-5, Djulfian; (b) Geinitzina postcarbonica Spandel., x e long.sec Gahkum sec., Dalan Fm., sample no.,33-1, Early Murghabian; (c) Geinitzina chapmani Schubert., sul.,x e long.sec Gahkum sec., Dalan Fm., sample no.,60-1,60-2 , Djulfian; (d) Pachypholoia cukurkoyi (civrieux\&Dess)., x e long.sec Gahkum sec., Dalan Fm., sample no.,38-2, Early Murghabian; (e) Langella cukurkoyi (civrieux\&Dess)., x e long.sec Gahkum sec., Dalan Fm., sample no.,46-10, Djulfian; (f) Pachypholoia pedicula Lange.,x e long.sec Gahkum sec., Dalan Fm., sample no.,46-6, Djulfian; (g) Langella conica de Civrieux \& Dessauvage..,x e long.sec Gahkum sec., Dalan Fm., sample no.,29-2, Early Murghabian; (h) Langella perforate Lange.,x e long.sec Gahkum sec., Dalan Fm., sample no.,70 , Djulfian.

valvulina sp., Agathammina sp., Glomospira sp., Geinitzina sp., Miliospirella sp., Fusulinids

The following algae also point to Dalan Formation:

Diplopora pusilla, Tubiphytes obscurus, Permocalculus plomasus, Gymono- 


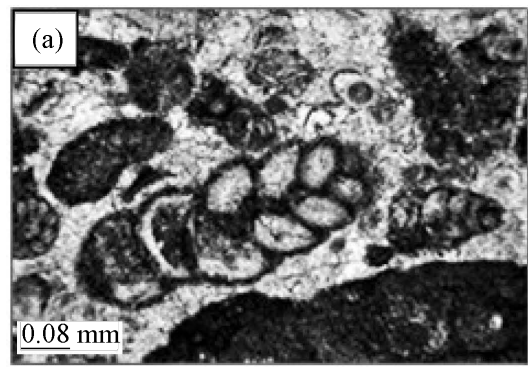

$0.08 \mathrm{~mm}$
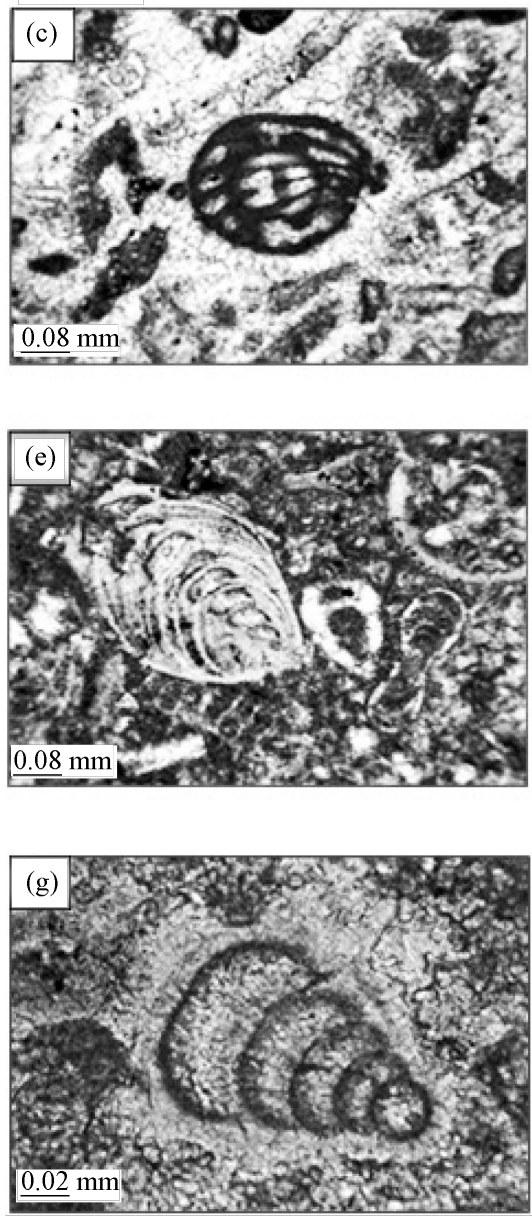
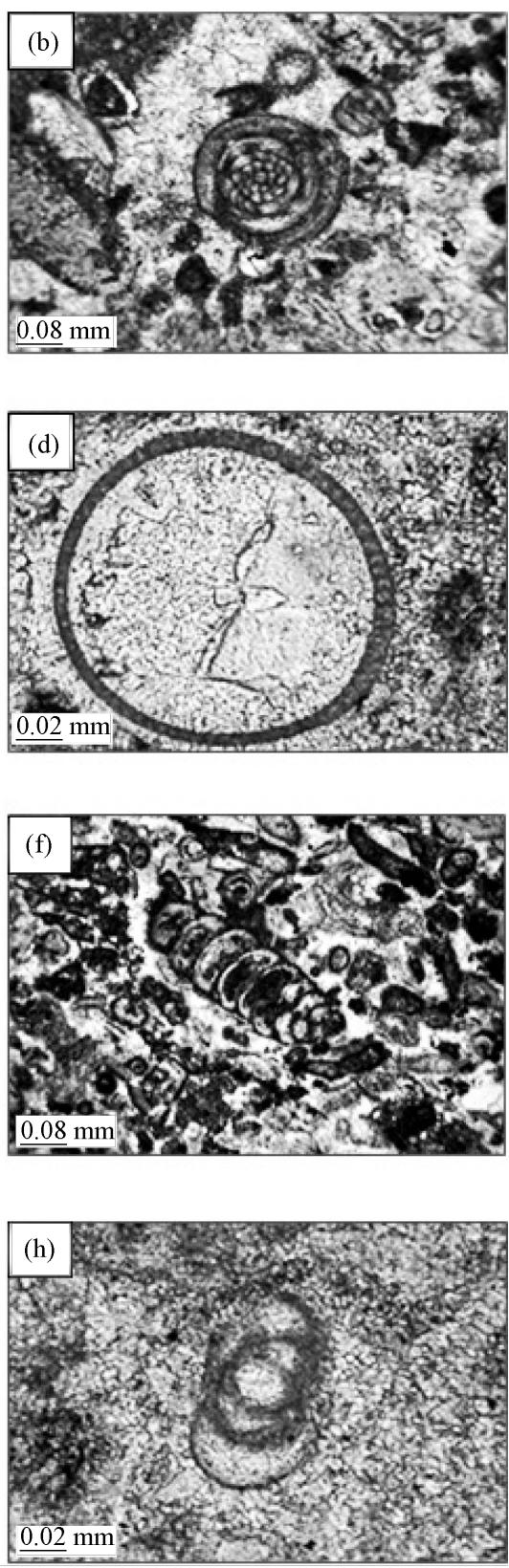

Plate 3. (a) Deckerella composita Reitlinger.,sul.,x e long.sec Gahkum sec., Dalan Fm., sample no.,66-5b , Djulfian; (b) Mesoschubertella thompsoni Sakagami.,x e long.sec Gahkum sec., Dalan Fm., sample no.,66-5a, Djulfian; (c) Schubertella transitoria, wedekind.,x e long.sec Gahkum sec., Dalan Fm., sample no.,48-2, Djulfian; (d) Tuberitina collosa Reytinger.,x e long.sec Gahkum sec., Dalan Fm., sample no.,53-2, Djulfian; (e) Fusulina sp.,x e long.sec Ghahkum sec., Dalan Fm., sample no.,51-1,51-3, Djulfian; (f) Protonodosaria praecursor (R.chern).,x e long.sec Gahkum sec., Dalan Fm., sample no.,57-2, Djulfian; (g) Frondina permica civri.\&Dess.,x e long.sec Gahkum sec., Dalan Fm., sample no.,58 , Djulfian; (h) Zarodella farsensis(n.sp.),x e long.sec Gahkum sec., Dalan Fm., sample no.,68-4, Djulfian.

codium bellerophontis, Macroporella apachena

3- Julfin time period (Late Permian), which is also marked by the presence of the following foraminifera: 

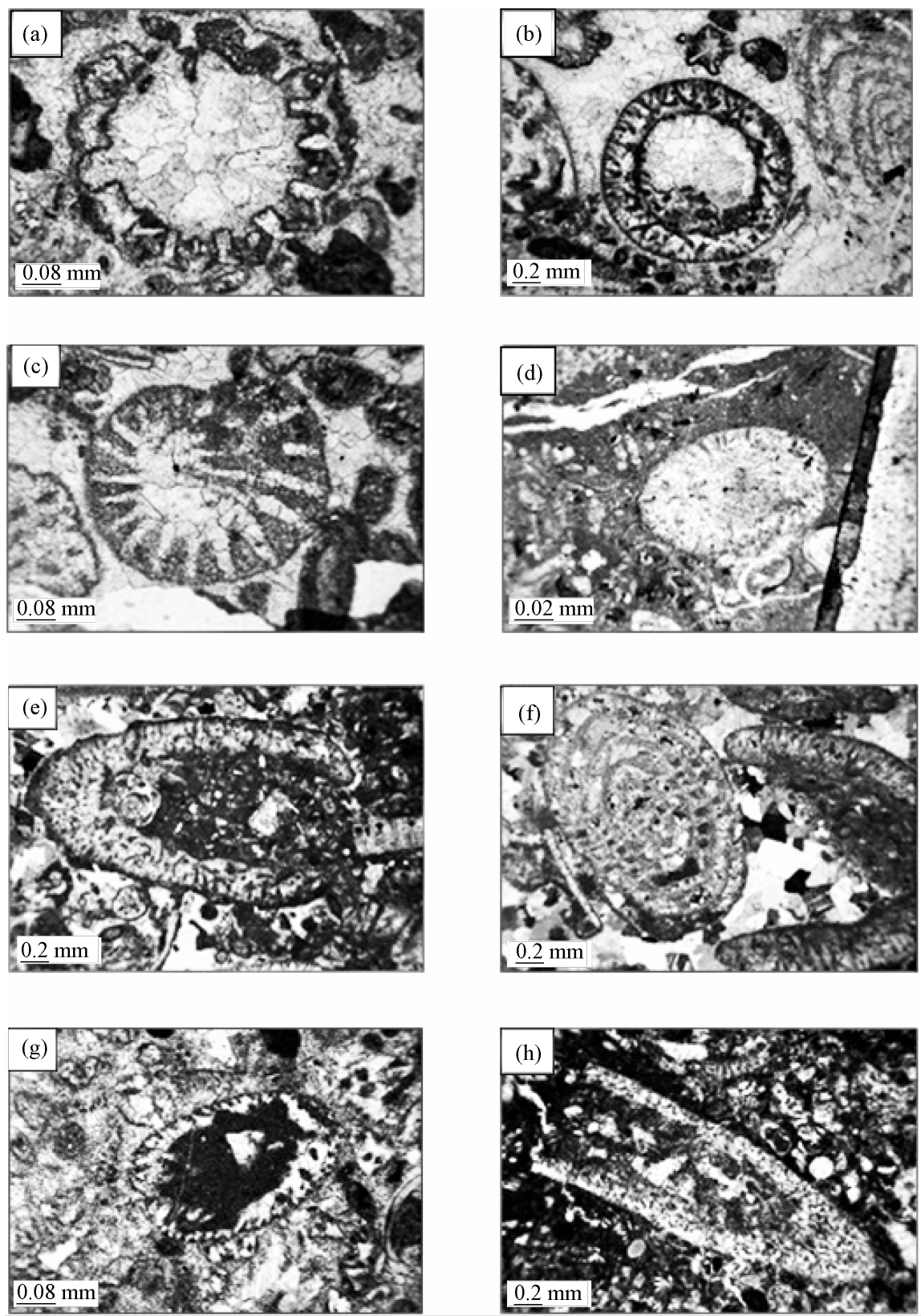

Plate 4. (a) (b) Macroporella apachena Johnson., x e long.sec Gahkum sec., Dalan Fm., a: sample no.,49-2, Djulfian, (b), sample no.,41-4, Late Murghabian; (c) (e) Permocalculus plumosus Elliott.,x e long.sec Gahkum sec., Dalan Fm., (c): sample no.,42-12, Late Murghabian. (e): sample no., 42-11, Late Murghabian; (d) Gyeroporella symetrica Joh.,x e long.sec Gahkum sec., Dalan Fm., sample no.,40-1, Late Murghabian; (f) Tubiphytes obscurus Maslov.,x e long.sec Gahkum sec., Dalan Fm., sample no.,42-13, Late Murghabianl (g) Gymnocodium bellerophontis (Rothpletz).,x e long.sec Gahkum sec., Dalan Fm., sample no.,46-8, Djulfian; (h) Permocalculus digitalus Elliott.,x e long.sec Gahkum sec., Dalan Fm., sample no.,68-3, Djulfian.

Geinitzina uralica, Langella cukurkoyi, Lasiodiscus tenuis, Geinitzina chapmani, Pachyphloia iranica, Langella acuntha, Cryptoseptida anatoliensis, Pseudotristix solida, Paraglobivalvulina mira, Frondina permica, Protonodosaria praecuror, Dekerella clavata, Langella conica, Dagmarita chanakchiensis, Codo- 
nofusiella ussuriensis, Dunbarula mathieui, Mesoschubertella thompsoni, Geinitzina primitive, Zarodella farsensis, Langella perforate, prondiscus sp., Dekerella sp., Codonofusiella sp., Climacammina sp., Protonodosara sp., Rectostipolina sp., Palaeotextularia sp., Tetrataxis sp., Hemigordius sp.

The following algae were also found in the mentioned time period of Dalan formation:

Diplopora pusilla, Tubiphytes obscurus, Permocalculus plomasus, Gymonocodium bellerophontis, Macroporella apachena, Macroporella maxima, Egoniolina johnsoni, Epimastopora regularis, Permocalculus fragilis, Vermiporella niponica, Gyeroporella symetrica, Permocalculus plumosus, Calvezia cf. ottoman, Permocalculus forcipinus, Permocalculus digitalus, Atractyliopsis sp., Aojgalina sp.

Besides foraminifera and algae, gastropod, brachiopod and ostracod are also found in the Permian system of the sample section.

\section{Acknowledgements}

We would like to express our special thanks of gratitude to Mr. Hossein Patovazar who helped us to identify microfossils. A special gratitude we give to $\mathrm{Mr}$. Mostafa Shahrabi and Dr. Mohammad Yusefi form University of Tarbiat Modarres, who aided us to take necessary photos from the sample sections.

\section{References}

[1] Kashfi, M.S. (1992) Geology of the Permian Super-Giant Gas Reservoirs in the Greater Persion Gulf Area. Journal of Petroleum Geology, 15, 465-480.

[2] Szabo, F. (1977) Permian-Triassic Stratigraphy Zagros Basin, South West Iran. NIOC unpub. Rep. No. 1261.

[3] Szabo, F. and Kheradpir, A. (1978) Permian and TRIASSIC Stratigraphy, Zagros Basin, Southwest Iran. Journal of Petroleum Geology, 1, 57-82.

[4] Aghanabati, S.A. (2006) Geology of Iran: Geological Survey of Iran. 586 p. (In Persian).

[5] Aghanabati, S.A. (2009) An Encyclopedia of Iranian Stratigraphy, Vol. 2, DevonianPermian, Geological Survey \& Mineral Explorations of Iran, 1297.

[6] Ghavidel Syooki, M. (1988) Palynostratigraphy and Paleoecology of the Faraghan Formation of South-East Iran. Ph.D. Theses, Michigan State University, East Lansing, $279 \mathrm{p}$.

[7] Ghavidel-Syooki, M. (1990) The Encountered Acritarchs and Chitinozoan from Mila, Ilebek, Zard-kuh Formations in Tang-e-Ilebek at Zard-kuh Region and Their Correlation with Palaeozoic Sequence in Chal-isheh Area in Zagros Basin of Iran. Symposium on Diapirism with Special Reference to Iran. Geol. Surv. Iran, 1, 141 218.

[8] Bakhtiari, S. (1984) Atlas of Iran Roads. Gitashenasi Publication, 140, p. 86.

[9] Locblich. A.R. and Tappan, H. (1988) Foraminiferal Genera and Their Classification. 2. Volume Van Nostrand Reinhold Companu. New York. https://doi.org/10.1007/978-1-4899-5760-3

[10] Khosrowtehrani, Kh. (1992) Applied Micropaleontology. University of Tehran Publication, Tehran, No. 2114, p. 257. 
[11] Kalantari, A. (1986) Microscopic Facies of Iranian Carbonate Rocks. Iran National Oil Company, Tehran, No. 11.

[12] Fakhari (1996) Bandarabbas City, at 1:250000 Scale: Geology of Exploration. Iran National Oil Company, Tehran.

[13] Sabzehei, M. (1993) Hajiabad City at 1:250000, Geological Survey \& Mineral Explorations of Iran.

[14] Dunham, R.J. (1962) Classification of Carbonate Rocks According to Depositional Texture. In: Ham, W.E., Ed., Classification of Carbonate Rocks, American Association of Petroleum Geologists Memoir, 108-121.

[15] Motiei, H. (1994) Zagros Stratigraphy. Geological Survey \& Mineral Explorations of Iran.

Submit or recommend next manuscript to SCIRP and we will provide best service for you:

Accepting pre-submission inquiries through Email, Facebook, LinkedIn, Twitter, etc. A wide selection of journals (inclusive of 9 subjects, more than 200 journals)

Providing 24-hour high-quality service

User-friendly online submission system

Fair and swift peer-review system

Efficient typesetting and proofreading procedure

Display of the result of downloads and visits, as well as the number of cited articles

Maximum dissemination of your research work

Submit your manuscript at: http://papersubmission.scirp.org/

Or contact ojg@scirp.org 